\title{
Italian Architectural Heritage and Photovoltaic Systems. Matching Style with Sustainability
}

\author{
Stefania De Medici
}

Citation: De Medici, S. Italian Architectural Heritage and Photovoltaic Systems. Matching Style with Sustainability. Sustainability 2021, 13, 2108. https://doi.org/10.3390/ su13042108

Academic Editors: Francesco Nocera and Marianna Rotilio

Received: 2 January 2021

Accepted: 9 February 2021

Published: 16 February 2021

Publisher's Note: MDPI stays neutral with regard to jurisdictional claims in published maps and institutional affiliations.

Copyright: (c) 2021 by the author Licensee MDPI, Basel, Switzerland. This article is an open access article distributed under the terms and conditions of the Creative Commons Attribution (CC BY) license (https:// creativecommons.org/licenses/by/ $4.0 /)$.
Department of Civil Engineering and Architecture, SDS of Architecture, University of Catania, 96100 Siracusa, Italy; stefania.demedici@unict.it; Tel.: +39-0931-489-454

\begin{abstract}
Rehabilitation and management of pre-industrial architectural heritage over time has played a central role in the international scientific debate since the 1970s. In light of the experience gained in this field, the challenge of a controlled and consistent integration of Renewable Energy Sources (RES) requires a careful reflection on the compatibility criteria between new technologies and traditional building's identity. Several of these technologies, such as photovoltaic (PV) systems, need to be placed on the building envelope or in appropriate outdoor areas, altering the architectural image and the landscape. Therefore, the characteristics of each building and its context should lead designers to choose solutions able to balance the need for increased energy production from RES with the need for preserving the identity of architectural heritage and landscape. A preliminary evaluation of rehabilitation projects allows to improve building sustainability and, in the meanwhile, to prevent any irreversible alteration of the cultural heritage. With reference to Italian case studies and guidelines for improving sustainability in energy production, the paper leads to identify evaluation criteria for the introduction of PV systems in pre-industrial buildings. Such criteria, which are based on architectural heritage values, allow for assessing the consistency of the building envelope alteration with conservation issues, in projects involving PV and, generally, solar technologies that need to be integrated with the building envelope.
\end{abstract}

Keywords: building rehabilitation; architectural heritage; photovoltaic systems; integrability criteria; contemporary art; industrial design; sustainability

\section{Introduction}

Globalisation is a central issue in the current debate on the Earth's future and is a process bringing both benefits and challenges. It can provide great opportunities for economic growth, improving the quality of life for many people. Nevertheless, it is also a threat to workers, local economies, and the environment, as it allows companies to relocate their businesses from one country to another, to take advantage of lower production costs. According to Douglas Kellner, «globalization critics assert that globalization produces an undermining of democracy, a cultural homogenization, and increased destruction of natural species and the environment» [1]. In particular, global challenges include the need to address two disruptive phenomena that directly affect the built environment: the use of energy from non-renewable sources and the loss of local identities.

How is Europe responding to global challenges? To fight globalisation's dangerous effects, in recent years the European Community has assumed ambitious goals concerning climate change, environmental degradation, use of non-renewable resources, and the social and economic crisis, to increase a sustainable lifestyle. Such goals broadly overlap with the strategies defined by the United Nations in the 2030 Agenda and the New Urban Agenda [2,3]. Notably, the Urban Agenda for the European Union, as adopted in 2016, aims to set up a process of city involvement in European policy-making [4]. Its twelve key issues include energy transition and the circular economy. A similar approach can be observed in the European Green Deal, the new growth strategy outlined by the European Commission 
and launched at the end of 2019 [5], as well as in the subsequent "Investment Plan for a Sustainable Europe/European Green Deal Investment Plan" [6]. The proposal includes significant investments in all relevant economic domains, with considerable funding, to achieve the 2030 climate and energy targets (reducing greenhouse gas emissions by at least $40 \%$ compared to 1990 levels; producing at least 32\% of energy from renewable sources, and improving energy efficiency by at least $32.5 \%$ ).

Regarding the built heritage, in particular, the Green Deal highlights the need to launch a "renovation wave" of public and private buildings, whereas the current annual renovation rate in the Member States varies only between $0.4 \%$ and $1.2 \%$ [7]. Strengthening the rehabilitation goal of the building stock is enshrined in the Commission's October 2020 Communication entitled "A Renovation Wave for Europe-greening our buildings, creating jobs, improving lives" [8]. It targets a doubling of annual energy renovation rates over the next ten years, improving people's quality of life, enhancing their living spaces, reducing Europe's Greenhouse Gas Emissions (GHG), and generating an extra 160,000 green jobs in the construction industry. The Communication highlights how the COVID-19 pandemic is changing our lifestyles and future prospects. Home became our primary living environment, revealing its inadequacy to meet today's needs. Millions of Europeans are using their homes as offices for those teleworking, schools for children and teens, university classrooms, spaces for leisure, reading, playing, and even online shopping.

Meanwhile, investment in the construction industry is a key target for economic development in the Old Continent. Rehabilitation projects are a source of additional jobs for the whole production chain and, in a virtuous circle, increase the demand for retrofitting with new technologies, stimulate demand for energy-efficient equipment and raise property values. Nevertheless, the data reported by the European Commission are not very encouraging, as they show that Europe is still far from its targets. In fact, the EU needs to reduce GHG emissions from buildings by $60 \%$, their energy consumption by $14 \%$, and energy consumption of heating and cooling by $18 \%$, to achieve at least a $55 \%$ reduction in emissions by 2030 [8].

The European policies for reducing energy consumption from non-renewable sources have, to date, had a significant impact on the energy efficiency of many new buildings, which consume less energy of those built before the 21st Century. The greatest challenge for the European Union involves the real estate built in the past Millennium, which amounts to $85 \%$ of the whole European building stock and is still far from the end of its life-cycle (85-95\% of these buildings are expected to still be standing in 2050) [8,9]. Improved energy efficiency and integration with Renewable Energy Sources (RES) is urgently needed for this part of the building stock. This goal can be achieved in the forthcoming years by using the EU's recovery instrument NextGenerationEU, geared towards making buildings more usable and sustainable, especially considering the progressive demographic aging.

The key principles of this strategy are the following:

- «"Energy efficiency first" as a horizontal guiding principle of European climate and energy governance and [ ... ] to make sure we only produce the energy we really need;

- Affordability, making energy-performing and sustainable buildings widely available, in particular for medium and lower-income households and vulnerable people and areas;

- Decarbonisation and integration of renewables [ ... ];

- Life-cycle thinking and circularity [ ... ];

- High health and environmental standards [ ... ];

- Tackling the twin challenges of green and digital transitions together [ ... ].

- Respect for aesthetics and architectural quality. Renovation must respect design, craftsmanship, heritage and public space conservation principles» ([8]; p. 3-4).

Such an ambitious programme should also consider the positive impact that investment in the construction sector could have in terms of cultural heritage conservation. 
Cultural heritage is the key element in the creation of a common identity for the Member States and is a crucial asset as Europe competes on the world stage of globalisation.

The heterogeneous building heritage is considered as an expression of cultural diversity and history of Europe. According to Oriane Calligaro, «The introduction of the concept of European cultural heritage on the Community's agenda in 1974 is an attempt to incarnate European identity, beyond abstract political principles» [10]. Identifying the elements of European heritage is not very difficult in terms of universally recognised criteria, but there are several problems in defining appropriate criteria for all Member States in view of the diversity and multiplicity of their different cultures [11].

European cultural action has clearly shown attempts to promote common historical and cultural roots, a common European heritage, presented as the materialisation of shared heritage values. Since the 1980s, the expansion of European heritage has progressively incorporated diverse local cultures and minority expressions. As a result, the understanding of the diversity of European culture has evolved beyond the diversity of national cultures to incorporate this sub-national level. Since the mid-2000s, cultural diversity has been presented both as a challenge to social cohesion to be addressed and as a value to be promoted [10]. Because of this wide range of cultural contributions from the populations of the European Union, it is not always easy to define common rules and criteria for the preservation of the building heritage.

In the light of the above reflections, Europe is facing a huge dilemma: how to upgrade its architectural heritage according to Green Economy criteria, while preserving the stone memory of buildings with cultural value? Can we draw up a framework of general rules, according to which we can assess the acceptability of transformations?

Focusing on the Italian context, the present paper aims to analyse the integration criteria of solar technologies and, in particular, photovoltaic systems in historic buildings, as an example of architectural heritage retrofitting to requirements of energy production from renewable sources. Solar technologies allow to capture, accumulate and use solar radiation to produce electrical or thermal energy through the following three primary technologies: concentrating solar power (CSP), which uses thermal energy from the sun to drive electric turbines; solar heating and cooling (SHC) systems, which harvest thermal energy from the sun to heat or cool the air and provide hot water; and photovoltaic $(\mathrm{PV})$, which converts light into electricity. These systems, since they need to capture solar radiation, must be placed on the building envelope or in an adjacent outdoor space. In particular, the photovoltaic technologies are based on the use of cells that can be embedded in different supports (panels to be placed on the roof or smaller elements, such as glass plates, tiles, etc.). The main problems of integration of PV systems with the architectural heritage are the impact on the image of the building, on the conservation of its elements and, therefore, on its identity. This impact consists of alterations in volumes and shapes, materials and surface characteristics (colour, texture, grain, etc.).

This study investigates the actual effectiveness of integration criteria of PV systems in preserving the identity of architectural heritage and landscape and proposes changes to the evaluation process. The paper consists of 5 Sections. Section 2 discusses the cultural, economic, and regulatory backgrounds leading to the issue of PV systems integration in pre-industrial buildings. Section 3 outlines the method used to define compatibility assessment criteria for integrating solar technologies with the envelope of historic buildings. Section 3.1 focus on assessment criteria provided by the Italian Ministry of Heritage, Cultural Activities and Tourism and scientific literature, to compare the sets of provided criteria. In Section 3.2 examples of the integration of PV systems on the roofs of pre-industrial buildings are analysed, highlighting both advantages and disadvantages related to conservation goals, as well as the compliance with the criteria considered in Section 3.1. Section 4 proposes a model for a two-stage evaluation process, consisting of a pre-assessment grid and a set of criteria to enable multi-criteria evaluation of integration projects. Section 5 summarizes the main results of this research and outlines future developments. 


\section{Background}

Cultural heritage, including landscape, is the result of a layering process spanning centuries. Italy holds an extraordinary cultural and landscape heritage, despite being one of the least generous countries in Europe in funding culture. The 2019 ISTAT BES Report highlights the need to strengthen the focus on preservation measures, tracking a decline in concern about landscape degradation and a growth, albeit moderate, in unsatisfaction related to the landscape of living places [12]. Such evidence confirms a reduction in social concern for the landscape quality. Furthermore, wide structural imbalances and inequalities still persist. These signals reveal that the principle of protecting the landscape and cultural heritage started in the Italian Constitution is not being fully implemented throughout the country, and specifically in Southern Italy.

Italy's architectural heritage consists of approximately 2,147,400 residential buildings built before 1919 [13]. The constructive quality of this heritage is as important as its exterior and requires careful knowledge to understand its meaning and hence its value [14]. In an architecture based on the use of stone, brick and wood, the introduction of systems which are necessarily placed in view on the building envelope can only result in problems and contrasts [15].

Adapting heritage buildings to a Green perspective is becoming an urgent need, especially in Italy, where cultural and landscape heritage has long been an essential driver of development.

Energy efficiency in historic buildings could prove to be a powerful means of promoting preservation [16]. Focusing on energy efficiency leads to designing more detailed and tailored technological solutions. Moreover, energy efficiency is an essential element of efficient economic management of historic buildings, which improves their usability. In the scientific community, many authors agree on the idea that the use of a heritage building is the most effective means of protection, as it promotes constant maintenance and allows the building to be passed down to future generations [16-19].

To contribute to a possible balance between innovation and traditional building culture, the characteristics of each building and its context should lead designers to find balanced solutions. The rehabilitation projects should increase renewable energy production and preserving the identity of the architectural heritage, as well as controlling the impact on the landscape.

\subsection{Balancing Heritage Conservation with Innovation. The Cultural Framework}

The issues of physical evidence of past eras, their contemporary significance and, in particular, the preservation of architectural heritage with cultural value are central concerns of scientific debate since the 19th Century [20,21]. Cultural heritage can be described as a category of cultural values (both tangible and intangible) shaped by the political, economic and social circumstances of the present. Therefore, it is at once tangible matter and intangible cultural expression, as well as the meanings ascribed to it and its representations [22].

In Italy, a huge number of heritage buildings are still standing today as the result of a cultural heritage management model based on the awareness that the national heritage is a system of interrelated goods and territories. Each cultural resource is considered as being part of the national identity and requires rules to preserve its civil and symbolic function [23]. The widespread presence of cultural heritage in the built environment, which is the current living space of people, requires a balance between the need to protect the evidence of the past and the need to adapt it to the requirements of contemporary life. Abandonment of historic buildings speeds up the degradation process, with negative impacts on the real estate value as well as on the overall quality of the urban area [19]. Indeed, an advancing state of decay of a building triggers a chain process, undermining the conservation status and the perception of safety in the urban area, the range of settled activities, the local services, etc. [24]. 
Building rehabilitation is essential if the buildings and their context have cultural value. Indeed, cultural heritage is a key resource for sustainable development, as it contributes to economic growth, job creation and social cohesion. In this perspective, cultural heritage should also be considered a non-renewable resource, because it cannot be replaced or reproduced. Despite technological development nowadays allows the reproduction of cultural heritage and works of art, the characteristics of uniqueness, originality and unrepeatability defined by Walter Benjamin as aura remain unreproducible [25]. The preservation of the authentic material substance of cultural heritage preserves the unrepeatable uniqueness of the creative act. Indeed, the outcome of the technical action leading to the production of the work of art or artefact is original and cannot be fully duplicated, as it is the result of a process of construction of history and traditions of a social group. When duplicating, some of the information is lost; this weakens the knowledge process, impairing perception and understanding.

Beyond the symbolic value deriving from originality, heritage buildings are irreproducible due to technical factors, such as the difficulty of finding materials once widely available or the loss of workers' skills in traditional construction techniques. The unrepeatability of heritage buildings leads us to consider them as tangible evidence of the building culture of past eras.

The Faro Convention on the Value of Cultural Heritage for Society [26] highlights the need for sustainable use of cultural heritage, «by ensuring that decisions about change include an understanding of the cultural values involved» and «that all general technical regulations take account of the specific conservation requirements of cultural heritage» (Article 9). The UNESCO Operational Guidelines for the Implementation of the World Heritage Convention [27] emphasize that the goals of sustainability should not jeopardize the conservation of the heritage; Article 119 declares that «World Heritage properties may support a variety of ongoing and proposed uses that are ecologically and culturally sustainable. The State Party and partners must ensure that such sustainable use does not adversely impact the outstanding universal value, integrity and/or authenticity of the property. Furthermore, any uses should be ecologically and culturally sustainable. For some properties, human use would not be appropriate». In the view of Luigi Fusco Girard, cultural heritage has a complex value, which includes use-value and also value independent from use, based on its cultural significance [28]. The need to preserve this heritage while preserving its complex value requires careful evaluation of building restoration projects, which should balance conservation and adaptation to protect the building and enhance its potential.

The unavoidable transformations required by new uses or, more often, the need to increase performance levels have stimulated the cultural debate on the balance between preservation and transformation of heritage buildings [29]. Indeed, a large number of historic buildings have been designed to meet needs that are quite different from the contemporary ones. Changes in our lifestyles and activities, as well as the evolution of technologies and their indispensable role in everyday life, have led to a radical change in the standards required for usability, safety and comfort in living spaces.

The concept of transformation management is a new research focus [30]. Nowadays, several studies focus on how to ensure the effectiveness of conservation strategies and how to accomplish a conservation approach which does not impair development.

An inappropriate approach to the rehabilitation of cultural heritage may neglect the issues of authenticity and conservation. Building rehabilitation works which do not focus on these issues could erase several centuries of history and cultural values, as highlighted by the ICOMOS document released for the international conference "Cherishing HeritageQuality principles for intervention on cultural Heritage", held in Venice in 2018. The document claims that «defining quality in the context of interventions on cultural heritage has progressed beyond architectural and technical matters at the level of single buildings to broader environmental, cultural, social and economic considerations about sites and their settings» ([31]; p. 15). 
Identifying the cultural value of a building is essential in designing rehabilitation choices. When people perceive the cultural value of a building or a site, they are more resistant to accept its transformation, because any alteration of the status quo is considered as a threat to its integrity. Effective approaches to building rehabilitation, as well as efficient management, are key steps towards the economic, cultural, social and environmental sustainability of a non-renewable resource such as cultural heritage. The development of cultural heritage goes far beyond the traditional economic framework of production and consumption of a specific good. The multiplicity of values and the mutual interaction of many different elements lead us to identify the cultural heritage system as an ecosystem. Indeed, when its elements exceed (or fall below) certain thresholds the cultural heritage system generates positive (or negative) dynamics [19].

Many international institutions (e.g., UN, UNESCO, ICOMOS) stress the key role of cultural heritage in the achievement of sustainable development, due to the intangible values of heritage, as well as the related economic processes. The international cultural debate, since the 1990s, shows a substantial change in the balance between conservation of the built heritage and innovation. This change is also reflected in design practices. The origins of this new approach can be found in the Nara Document on Authenticity [32], which links the preservation of cultural and heritage diversity with human development (art. 5). In particular, the document highlights the following two priorities: the need to extend the life cycle of cultural heritage and the need to involve in conservation a wide range of stakeholders.

Beyond the economic motivations, the choice to rehabilitate the huge historic building heritage meets the needs of sustainability, in terms of reducing soil consumption, reusing raw materials and manufactured products, as well as protecting and enhancing the architectural heritage. Commitment to quality is the main strategy to comply with the multi-faceted precepts of the Circular Economy concerning resources, capabilities, preservation and enhancement of embedded values [33]. The built environment is a key legacy of the cultural, social and economic stratification of urban fabrics [34]. Therefore, in circular thinking, loops should be closed not only through new solutions, but most effectively by redefining processes and strategies in design [31].

Building rehabilitation is consistent with a sustainable approach to urban and landscape management, according to a circular economy model, which «would turn goods that are at the end of their service life into resources for others, closing loops in industrial ecosystems and minimizing waste» ([35], p. 435). Nowadays, according to the issues of climate justice and the living planet, «It is unthinkable for anything to have no function, to be useless, to make no contribution to the betterment of society. The contemporary mantra "Reduce, Reuse, Recycle" is testament to this essential prerequisite of contemporary life. Everything has to be useful, and existing building cannot escape from this agency of usefulness» ([36]; XVIII).

The reuse practice dates back to ancient times, but nowadays we have a deeper understanding of its strategic importance. Considering the built environment as a resource does not only mean considering its value as the result of human work or as an artefact. The built heritage can also be valuable for its storytelling ability, for providing knowledge, for recalling the past, for being a symbol of events, traditions, shared knowledge, religions; in other words, it can be endowed with cultural value.

\subsection{Investing in Building Rehabilitation and Sustainable Development. The Economic Framework}

Data from the Construction Industry highlights the ever-increasing weight of investments in rehabilitation of the architectural heritage compared to new construction. The European construction industry in the new millennium is progressively shifting production targets from the construction of new buildings to the rehabilitation of the building stock [37-45]. The residential building stock in the Member States of EU is relatively old ( $21.6 \%$ was built before $1945,45.4 \%$ before 1969 , and $75.4 \%$ before 1990) [46]. Such data lead to the conclusion that without significant investment to improve energy performance, 
the average level of the energy performance of the EU real estate will remain low. There are structural problems in the overall scenario, such as population pressure, market saturation, and slow authorization and construction procedures. The leading market over the next years will be the infrastructure system.

According to the Construction Intelligence Centre (CIC) report, construction investment growth for the period 2018-2022 should have steadily slow in emerging markets, following Chinese trends, while increasing across Western Europe [47]. European construction output was expected to grow by an average of $2.4 \%$ per year over 2018-2022, with more investment in building renovation than new construction.

Therefore, the construction industry suffered an unexpected downturn during the second quarter of 2020 as a result of the Covid-19 pandemic. The restrictions imposed to contain the spread of the virus slowed and, at times, halted construction activity. Despite this crisis, many countries have shown signs of a rebound in business in the third quarter of 2020. Notwithstanding the new restrictions in the final part of 2020, the construction industry was allowed to continue its activities. As the vaccination campaign starts, the risk of a recurrence of the serious disruption experienced in 2020 is decreased in 2021. Based on this assumption, Global Data predicts that global production in the construction market will increase by $4.5 \%$ in 2021, following the estimated $2.9 \%$ contraction seen in 2020 [48].

In the European framework, Italian buildings include the largest pre-industrial heritage, with $30 \%$ of Italian buildings dating back to before World War II. Data surveyed by the Research Centre for Economic and Social Market for Construction and Territory (CRESME) reveal that in Italy the investments for building rehabilitation (including maintenance) increased from 56\% to $67 \%$ between 2006 and 2013. The investments for new construction decreased from $44 \%$ to $33 \%$ [49]. The decreasing population is one of the primary causes of this trend. These results also arise from tax incentive policies for building renovation and energy retrofitting, which have resulted in 19.5 million interventions from 1998 to 2019 (over $62.5 \%$ of Italian residential buildings, estimated by ISTAT at 31.2 million). In twenty years, tax incentives led to investments of almost 322 billion euros.

Rehabilitation strategy for pre-industrial buildings is required to reduce the land and material consumption and to address the need for cultural sustainability. Referring to the broadly shared academic view [50-52], as well as the campaigns by the United Nations Educational, Scientific and Cultural Organization (UNESCO) together with United Cities and Local Governments [53], culture is considered as the Fourth Pillar of Sustainable Development. Conservation theories have focused on change as a force capable of eroding the intrinsic value of cultural heritage. According to the UNESCO approach, the built environment can act as a driving force for development. Development progresses through change as an intrinsic component of its core [54].

In light of the extensive debate and data summarized in Sections 2.1 and 2.2, the relationship between cultural heritage and sustainable development can be considered in a dual perspective, one based on the aim of ensuring the sustainable use of cultural heritage and another considering cultural heritage as a driver for sustainable development (Figure 1). In the context of these two different approaches, the framework of references highlights a plurality of specific objectives to be pursued, as summarised in Figure 1. 


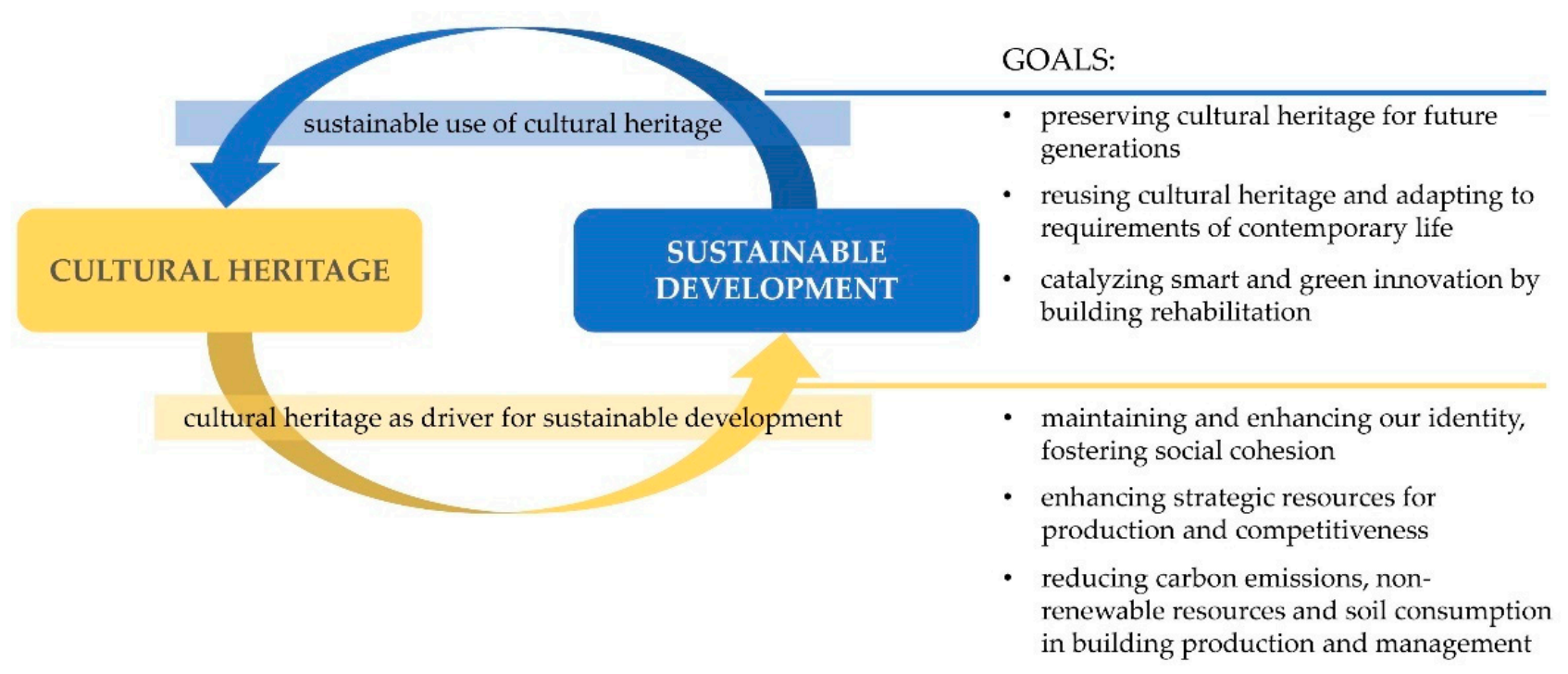

Figure 1. Outcomes of the cultural and economic framework. The dual perspectives in the relationship between cultural heritage and sustainable development.

\subsection{Defining a System of Rules and Guidelines. The Regulatory Framework}

In Europe as well as in Italy, several laws have been enacted to meet energy-saving targets, reducing fuel consumption and air pollutant emissions (primarily carbon dioxide), and also cutting expenditure on public real estate management. In the early 1990s, the Italian Law n.10/1991 «Regulations on the rational use of energy, energy-saving and development of renewable energy sources» introduces the use of renewable energy sources for energy management.

In the last twenty years, Italy has experienced a proliferation of laws on energy efficiency and RES use, as a consequence of the increasing pace of sustainability-oriented European policies. At the beginning of the 2000s, the EU Directive 2002/91/EC, adopted in Italy by Legislative Decree 192/2005, requires EU countries to define and apply a methodology for calculating the energy consumption of buildings. The rules of Legislative Decree 192/2005 are applicable to both public and private buildings. Nonetheless, for listed buildings under Legislative Decree n. 42/2004, the Consolidation Act on Cultural Heritage and Landscape, the application of Legislative Decree 192/2005 are subject to compatibility with the goal of cultural heritage preservation.

In 2009, besides the Italian Presidential Decree 59/2009, implementing regulation of Article 4, paragraph 1, letters (a) and (b), of Legislative Decree 192/2005, Italy enacts the Decree of the Ministry of Economic Development 26/06/2009, which defines the guidelines for building energy certification.

In 2011, Legislative Decree n.28/2011 adopts the European Directive 2009/28/EC and establishes the measures to achieve the 2030 targets for renewable energy. According to such decree, not only new buildings but also those involved in major refurbishment must produce at least $50 \%$ of the energy consumed from renewable sources. Nevertheless, the decree exempts from this obligation buildings protected by Legislative Decree n. 42/2004, as well as those protected by urban planning regulations, where compliance with RES requirements leads to an alteration of historic and artistic values. Yet again, the law seems to forego the possibility of a successful integration between RES technologies and heritage buildings.

The following Law 90/2013 set a condition for applying the prescriptions to protect assets and sites with cultural value, and the landscape. If the Italian Ministry of Heritage, Cultural Activities and Tourism (MiBACT) verifies that meeting the results of the prescription in a major alteration of characters or appearance of the cultural heritage or landscape, it provides for an exemption from the application of this law. Nonetheless, Law 90/2013 
takes a step forward by requiring the creation of a Working Group, including MiBACT managers and staff and academics, to provide operational recommendations to designers and Ministry staff. It developed technical criteria for the energy retrofitting of cultural heritage.

In 2015, the MiBACT published Guidelines, edited by the Working Group. These provide recommendations for assessing and improving the energy performance of the listed cultural heritage, with reference to Italian regulations on energy saving and energy efficiency in buildings. Considering the uniqueness and the specific characteristics of the buildings to which it refers, the rapid evolution of available technologies, as well as the potential future adaptations of technical standards and legal provisions, the document does not present standard solutions and is not mandatory. In the case of rehabilitation of cultural heritage, the primary purpose is conservation, accompanied by the subordinate objective of improving the level of energy performance, where possible.

The Guidelines also address the issue of the effects that energy-efficient rehabilitation projects can have on the historic urban landscape and, more generally, on the landscape. These guidelines focus on knowledge and interpretation of building information. Such information aims to cover its history, construction features, conservation status, evolution and transformations occurred-also with reference to its interaction with the urban contextas well as the current equipment and the environmental quality.

The Guidelines provide indications to evaluate the energy efficiency of cultural heritage and suggest some possible measures to improve its energy efficiency, also through the description of best practices.

Therefore, the Working Group created by MiBACT has filled the gap of systems upgrading in historic buildings, which is a key issue not only to ensure compliance with the law but also to address issues raised in the scientific debate. Such a gap encouraged the practice of invasive upgrading of systems also in heritage buildings, to improve comfort performance in line with the standards of new buildings.

Throughout these years, several laws have also contributed to encouraging energy efficiency as well as the installation of RES technologies in buildings. These include the Decree of the Ministry of Economic Development of 19 May 2015 which simplified the procedures for installing small photovoltaic systems integrated on buildings, the Article 14 of Decree-Law No. 63/2013, as amended by Law No. 160/2019, which introduced tax deductions for energy efficiency interventions, up to the new measures introduced by Decree-Law No. 34/2020, which allows for a 110\% deduction of expenses for energy efficiency. Nonetheless, the debate about compatibility is ongoing.

The European Community considers the issue of energy as a driving force for ensuring sustainable development. In recent years, this approach is expressed in increasing regulatory production. The EU Directive 2018/844 on the energy performance of buildings introduced a legislative framework intended to reduce carbon dioxide emissions by 2020, to increase RES and improve the energy performance of buildings [55]. In particular, the directive promotes research and development of new solutions for improving the energy performance of historic buildings and sites, while ensuring the protection and preservation of cultural heritage. The EU Directive 2018/2002 promotes measures on energy-saving mandates, energy efficiency mandatory regimes and alternative policy measures to convert the EU building stock in the long term to Near-Zero Energy Buildings.

Italy also reflects this trend. Legislative Decree No. 73/2020, which updated the previous Legislative Decree No. 102/2014, establishes several measures for energy efficiency aimed at the Italian energy savings target. Such measures contribute to implementing the European "energy efficiency first" principle. In particular, the decree allows for exemptions to regulatory requirements for some measures of energy requalification.

National laws are also supported by strategic planning documents, which define the targets to be achieved in the medium and long term. In early 2020 the Italian Ministry of Economic Development published the text of the Integrated National Energy and Climate Plan, drawn up in collaboration with the Ministry of the Environment and the Ministry of 
Infrastructure and Transport. The Plan includes the innovations introduced by the Climate Decree-Law (No. 111/2019), as well as those on investments for the Green New Deal, planned in the Budget Law 2020. The Plan establishes the national goals by 2030 on energy efficiency, renewable sources and reduction of $\mathrm{CO}_{2}$ emissions, defining the measures to be implemented.

Alongside EU and Italian legislation, in the second decade of 2000, the standardization organizations have increased their efforts on energy efficiency and RES technologies. Focusing on cultural heritage, in 2012 the European Committee for Standardization (CEN) established a workgroup dedicated to energy efficiency in historic buildings. The workgroup aims to develop European Standards to address the outstanding issue of energy efficiency in heritage buildings.

The Technical Committee CEN/TC 346 "Conservation of Cultural Heritage" prepared the UNI EN 16883:2017 standard, approved by CEN on 2017. The scope is providing guidelines for sustainably improving the energy performance of historic buildings while respecting their heritage significance. The UNI approach refers to buildings of heritage significance, considered as material manifestations of immovable tangible cultural heritage. Such buildings do not necessarily have to be statutorily designated as cultural heritage. The UNI EN 16883:2017 provides a working procedure for selecting measures to improve the energy performance of historic buildings and assessing their impact in terms of conservation. The standard refers to the definition of "compatibility" as the "extent to which one material can be used with another material without putting heritage significance or stability at risk» (EN 15898:2011, 3.3.3). The guidelines are designed to be used by clients (public and private building owners) and professionals. They provide guidance for selecting appropriate measures in the design phase and aim to find a sustainable balance between the use of the building, its energy performance and its conservation. UNI EN 16883:2017 guidelines do not specify compliant building solutions established beforehand but provide a procedure to assist in finding the best solution for each individual building. Knowledge is the key factor in the decision-making process and a multidisciplinary approach is required. The assessment and selection of measures for improving energy performance are based on seven assessment categories, including "heritage significance of the building and its settings". The assessment criteria related to such category are the following:

- risk of material, constructional, structural impact;

- risk of architectural, aesthetic, visual impact;

- risk of spatial impact.

The procedure suggests a qualitative assessment, based on a five-level scale, according to which to rate the hypothesised measures.

Outside the borders of Europe, in 2017 the International Energy Agency (IEA) Task 59 "Renovating Historic Buildings Towards Zero Energy" publish the EBC Annex 76 [56]. The Annex highlights multiple goals for energy retrofit of historic buildings. These include identifying and assessing conservation compatible retrofit solutions in a "whole building perspective".

\section{Materials and Methods}

Several studies address the issue of diffuse energy production, to overcome challenges and make urban centres and buildings energy self-sufficient [57-61]. The main issues for the Italian architectural heritage are the transformations of the building envelope required for the installation of roof solar technologies [62-65]. Not only scientists but also local administrations are involved in this issue. They have to reconcile the need to produce electricity and heat on-site, with the preservation of the building heritage and landscape [66-69]. The research of shared design criteria arises from the need of researchers and institutions to evaluate energy efficiency solutions for historic buildings.

The research methodology investigates the evaluation criteria recurring in the scientific literature and the criteria developed by the MiBACT Working Group, highlighting their 
extensive overlap. Such criteria, jointly with the risks outlined in the UNI EN 16883:2017 standard, are used to analyse a panel of Italian pilots.

\subsection{Review of Assessment Criteria for the Integration of Solar Technologies in Historic Buildings}

In Europe, Guidelines are issued by several governments and in several research projects on renewable energy integration in historic buildings $[55,70]$. The following recommendations are frequently provided by guidelines and research projects:

- adapting the photovoltaic modules to the inclination and the roof frame;

- grouping the panels;

- $\quad$ adapting the photovoltaic modules to the roof contours, ridge and eaves lines;

- $\quad$ adapting the photovoltaic modules to the pitch dimensions;

- covering up pipes, cable trays and anchoring elements;

- designing joints carefully;

- choosing colours and surface textures that complies with the old roofing.

The Canton of Ticino lists a number of problems relating to roofs, which affect the integrability with historic buildings or contexts [71]. The constraints identified concern the following cases:

- the roof is clearly visible or is in a prominent position in the landscape;

- the roof is clearly visible from an urban public space;

- the roof is part of a homogeneous area of the built environment;

- the roof is on a low building, highly visible from nearby buildings;

- the size of the pitch is unsuitable to contain the modules needed.

In Italy, the acceptability of installing RES technologies in heritage buildings or cultural landscapes, as argued by the MiBACT Working Group, should be considered on a caseby-case basis, balancing potential risks and benefits. Indeed, architectural heritage has a multidimensional value and the value categories are mutually dependent [72]. Long-term use and conservation, as well as the use of energy from renewable sources, require a management process which considers economic, ecological, and social values [73]. The most challenging cases are those in which both the risks and benefits of RES are equally high.

The integration of PV systems is also addressed by the Working Group by showing examples of best practices. Some are focused on installing panels on pitched roofs or vertical surfaces, others suggest alternative systems, using photovoltaic cells embedded in glass or in each single tile. A reflection on the limited advantages in terms of energy produced by installing PV systems on the roof of historic buildings emerges. If the pitch orientation and inclination are respected, the photovoltaic panels may not always be optimally positioned. In addition, the installation on the roof leads to a significant alteration of the image of the building and the landscape. This problem often leads to prefer the delocalization of energy production systems, a choice that does not solve the problem of the negative impacts on the landscape [74]. On the other hand, projects involving the inclusion of photovoltaic cells in the glass surfaces and experimental projects using industrial design elements (panels, display boards, etc.) are highlighted (Figure 2).

The main critical issues underlined by the Working Group concern the chromatic alteration of the architectural surfaces, as well as the impact on the landscape and the soil sealing, in case of ground installation of the systems. Guidelines for integrating PV panels on historic building roofs are the following:

- where possible, place panels on the roofs of outbuildings (e.g., pergolas on parking lots);

- use integrated solutions to replace roofing;

- study the disposition of the panels in a continuous band, above the eaves line, throughout the whole length of the roof or covering the entire pitch with better exposure to solar radiation;

- choosing panel colours consistent with the roofing colour. 


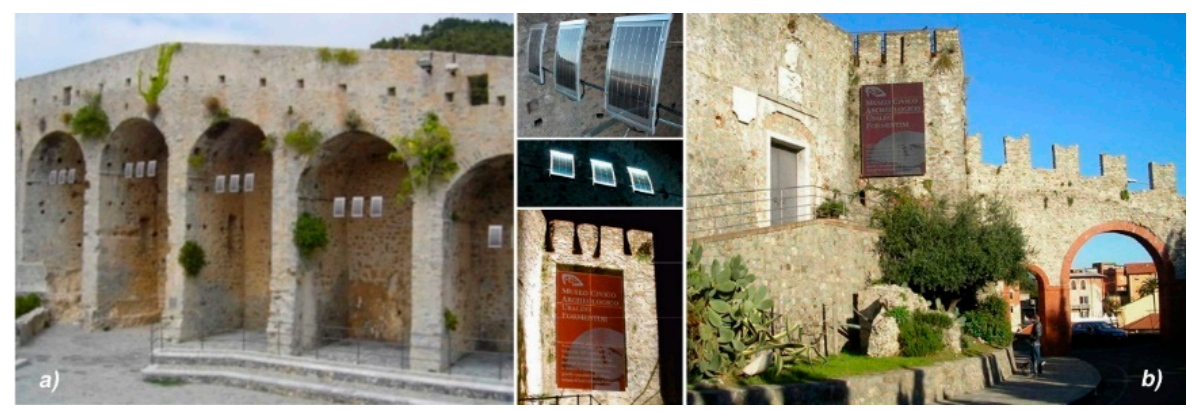

Figure 2. Installations of Renewable Energy Sources (RES) systems on heritage buildings. (a) Selfilluminating "Solar flags" on the Doria Castle in Porto Venere (Italy); (b) Display board in the façade of the La Spezia Archaeological Museum (Italy) [75].

To date, the installation of RES systems in the historic Italian centres, as elsewhere, remains the main problem to be overcome, to really improve the energy sustainability of the cities [76]. The building's previous function, layout, and interaction with the environment create multiple constraints, which impact any new use of the building [15,77].

Several pieces of research show that multi-criteria evaluation methodologies can support decision making to verify the compatibility of RES technologies with heritage buildings and to drive the choices of the integration project [78]. A relevant example is the research results achieved by Thebault et al., proposing an application of MCDA in a study on Geneva [79]. This research identifies the following five evaluation criteria:

- the constraint-induced by superstructure elements;

- solar irradiation;

- economic feasibility;

- the structural robustness of the roof;

- the heritage and aesthetic qualities of buildings.

In particular, the last criterion is graded following a visual criticality scale and refers to the research results of Munari Probst et al. [80-83]. This research relates the acceptability of integration to both the protection level of the building/district and the visibility of the roof from the street. However, this second information is not always reliable, so the study of Thebault et al. only considers the degree of heritage protection for the aesthetic criterion. Although the approach used to define the criteria on which this study is based is not always viable, the basic idea is widely shared in the scientific literature. According to this idea, the integration of photovoltaics on the roofs of historic buildings can have a negative impact not only on the building's identity but also on the landscape's integrity and the image perceived by people.

Currently in Italy, in the practice of building rehabilitation, the application of PV with panels on the roof is widespread. Panels are considered compatible if they are (partially or totally) installed in place of the roof covering, rather than overlapping. Another element considered in the evaluation of the project for permissions is the respect of the inclination and orientation of the roof pitches and the choice of a colour similar to that of the old roof covering.

The evaluation of projects submitted for approval to the Ministry often deals with areas and landscapes which have already been deeply altered. Often the sum of several minor alterations carried out by the population over time has led to a dramatically disrupted historic urban and rural landscape [84]. In such areas (which have already been jeopardized by superfetation, uncontrolled installation of systems, replacement of building elements with components unrelated to the local tradition) the introduction of RES systems with visible elements on the building envelope is an additional risk factor. Such risk gets serious when considering the multiplier effect produced by incentives and tax breaks.

The integration of PV systems with architectural heritage requires an approach to cultural heritage conservation based on scientific knowledge $[85,86]$. The MiBACT Guidelines propose a qualitative assessment of interventions on architectural heritage based on three 
main criteria: invasiveness, reversibility and compatibility. Nevertheless, the Working Group does not provide an official definition of these criteria, referring to consolidated principles in the field of Architectural Restoration disciplines. The ratings of each criterion are based on a qualitative assessment scale.

The analysis of the case studies leads to a revision of these criteria, to allow for practical application. Indeed, to be able to evaluate project alternatives with a multi-criteria evaluation system, we need unambiguous criteria, as well as an appropriate scale of values and directions [87,88]. Notably, the scale indicated in the forms included in the MiBACT Working Group report consists of three levels of judgment (high, medium, low). The direction is not specified. This can lead to inconsistencies in evaluation; i.e., a high score of invasiveness is negative, while a high score of reversibility or compatibility is a positive result.

Therefore, the criteria defined by the MiBACT Working Group have been reconsidered, to improve their usability and effectiveness in a multi-criteria evaluation. Going beyond the evaluations of technical and economic feasibility, the research has explored the evaluation criteria strictly related to the conservation purposes of the architectural heritage and landscape. A starting point for the identification of such criteria are relevant studies on the definition of cultural value and its role in shaping the quality of urban systems [89-93].

The proposed approach is consistent with the break-up of cultural value into its constituent elements as discussed by David Throsby in the case of heritage [72]:

- $\quad$ aesthetic value: beauty, harmony

- $\quad$ spiritual value: understanding, enlightenment, insight

- social value: connection with others, a sense of identity

- $\quad$ historical value: connection with the past

- symbolic value: objects or sites as repositories or conveyors of meaning

- $\quad$ authenticity value: integrity, uniqueness.

According to Throsby, «these values derive from a broadly cultural discourse about the significance of art and culture in human affairs. It is obvious that cultural value in this context is multidimensional, qualitative, subjective and likely to change over time» ([72]; p. 43).

\subsection{Study Cases}

The common practices of integration of systems and technologies for renewable energy use in historic buildings have led to a less theoretical approach in the scientific debate on this topic. The evidence of implemented interventions has allowed one to highlight the most relevant compatibility issues in the integration of PV systems with the pre-industrial architectural heritage.

The research has analysed examples of the integration of solar technologies on the roofs of pre-industrial buildings reported in the scientific literature or cited as examples in the guidelines of European governmental authorities. The conservation status and appearance of the buildings before the installation of the new rooftop solar systems is not available in all cases reviewed. Nonetheless, the available documentation revealed the strengths and weaknesses of the analysed projects in relation to heritage building and landscape identity preservation goals.

The study is based on the analysis of the integration of photovoltaic systems on the roof of pre-industrial buildings.

The design solutions implemented in the case studies have been compared both with the current recommendations outlined in the previous paragraphs for Italian historic buildings (MiBACT and UNI EN 16883:2017) and with the constraints to the transformation of heritage buildings identified in the scientific literature in the field of building rehabilitation [17,94-97]. Notably, the following constraints have been considered:

- perceptive-cultural constraints aimed at preserving symbolic, historic, stylistic and artistic features, respect for the collective memory, and aesthetic connections with the landscape;

- morphological-dimensional constraints aimed at preserving the geometric configuration and stereometric characteristics of the envelope; 
- material-constructional constraints aimed at preserving the building materials and techniques, as well as their performance.

The results of the analysis are summarized in Figure 3.

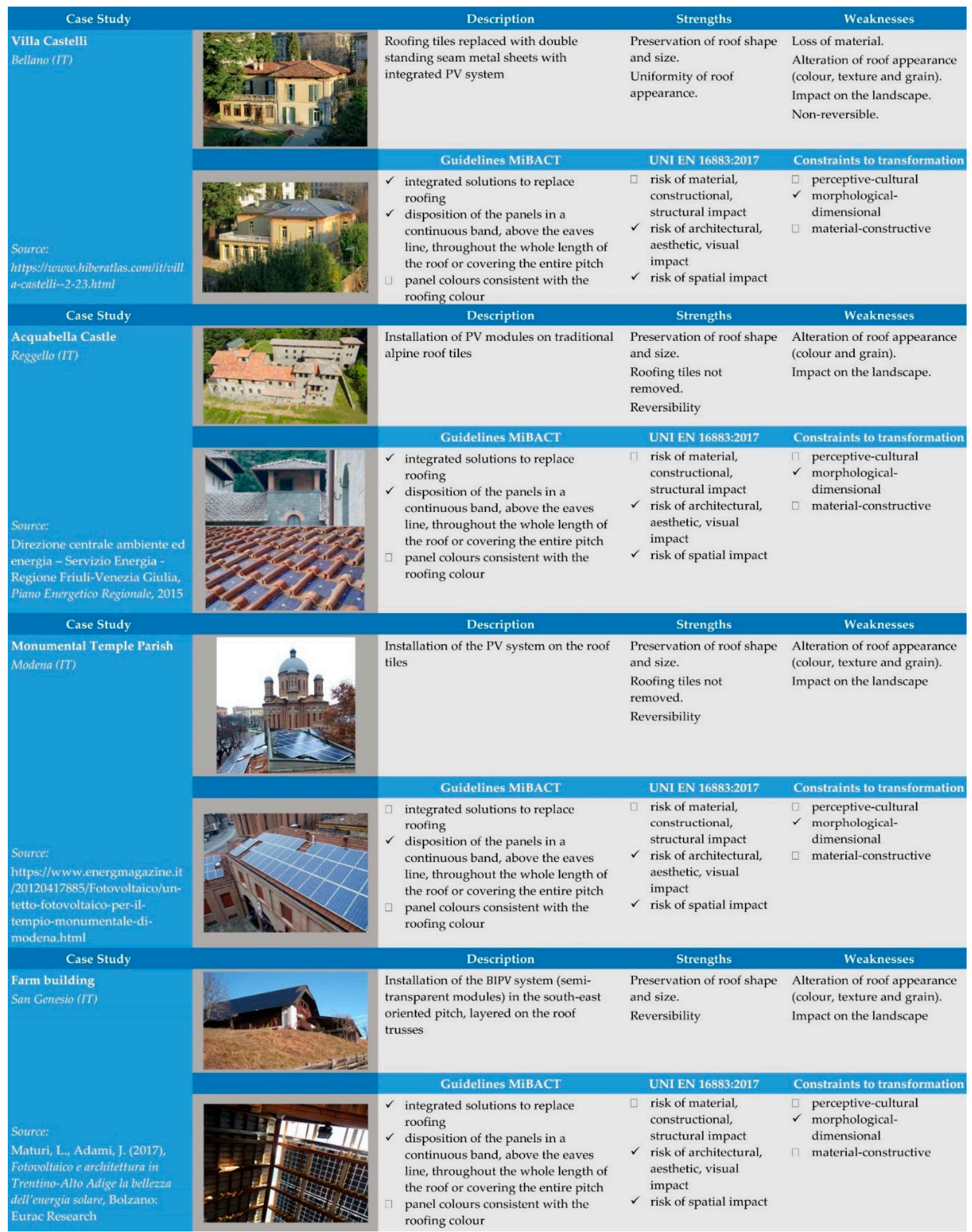

Figure 3. Analysis of study cases. 
The analysis of the study cases shows the need for an overall assessment of the project. In such examples of integration, while respecting most of the recommendations provided by guidelines (as well as those by the main research projects), the impact of transformations affecting the building envelope is far from being acceptable. The analysis highlighted that the analysed projects did not meet two out of three of the evaluation criteria indicated by the UNI EN 16883:2017 standard, referring to the assessment category "heritage significance of the building and its settings". Regarding the constraints to the transformation of the heritage buildings, in all the considered cases only morphological-dimensional constraints are complied with. The compliance of PV systems with shapes or colour of the roofs, as well as perceptive-cultural aspects of the transformations should be considered. Another key point is the impact on the natural and built environment in terms of an alteration of the local identity.

\section{Results and Discussion}

To date, the debate on cultural heritage restoration is still affected by the contrasting theories developed by Viollet-le-Duc and Ruskin in the 19th Century [98,99]. The manifold positions taken over time in the scientific community on the objectives to be pursued in the restoration project cannot in any case relieve the designer from the responsibility of the choice [100]. Culture, experience and sensitivity of the designer guide the decision-making process towards results that, to varying degrees, aim at the preservation of materials, the minimization of impacts and the protection of the landscape [101]. Therefore, evaluation criteria are certainly a useful guide in project choices, but they cannot transform the project from being a critical interpretation of reality to a mere implementation of set rules.

The results of the two phases of analysis led to hypothesize a revision of the compatibility assessment of projects for the application of PV systems to historic buildings. They also bring to the identification of new evaluation criteria, related to the aforementioned constraints to the transformation (Section 3.2).

\subsection{Criteria for Assessing Integration Project Quality}

The research led to a structuring of the criteria into main criteria and sub-criteria. The latter provides a more conscious judgment by the subjects involved in the evaluation (designers, staff of the MiBACT, engineers of local authorities, etc.) (Figure 4).
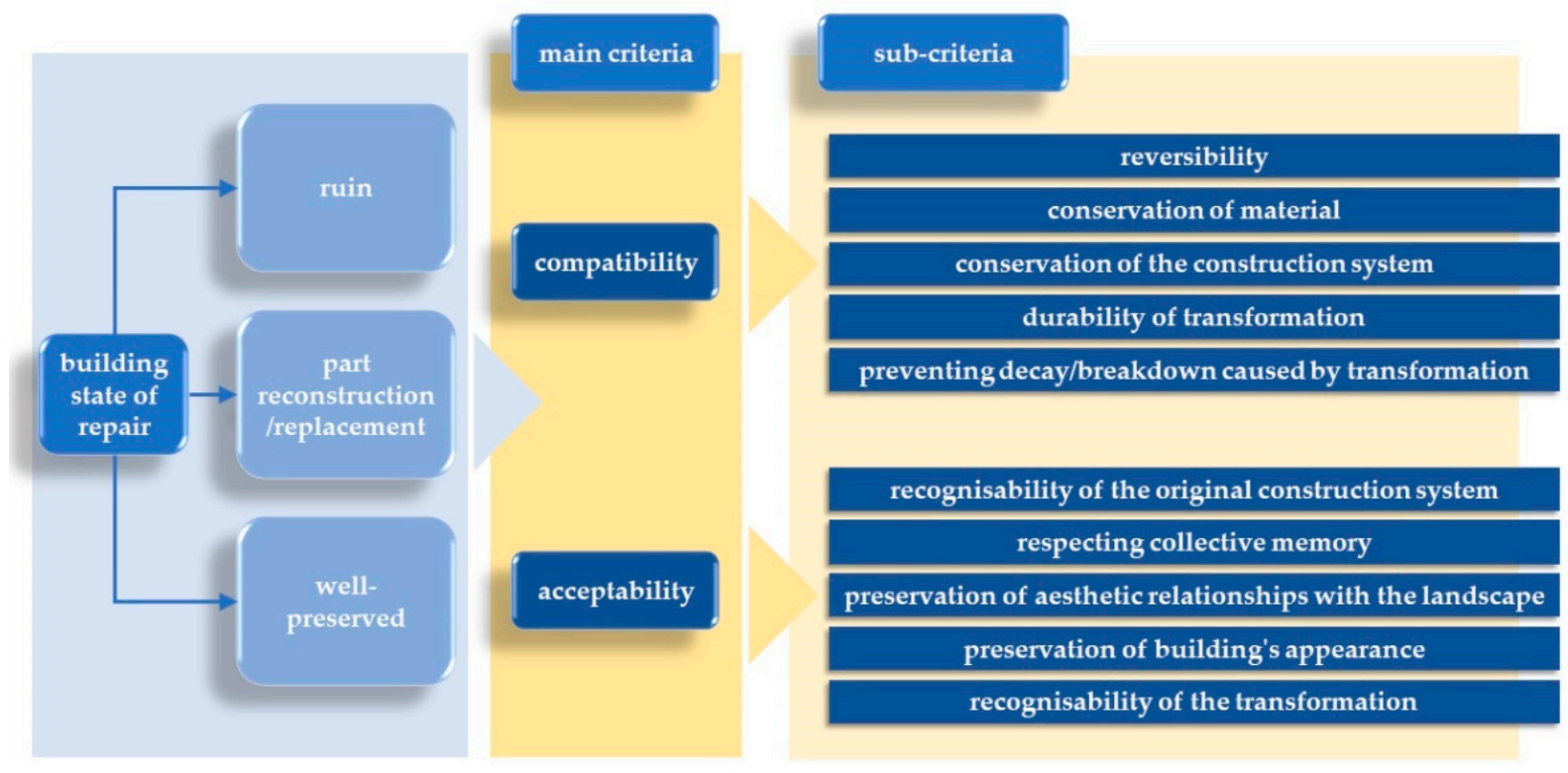

Figure 4. Classification of buildings referring to their state of repair and integrability criteria. 
The main criteria are identified as follows:

- Compatibility: The ability to avoid irreversible changes in the shape of the building or its elements and in the logics of construction; the ability to avoid degradations or breakdowns related to the installation of PV systems. The criterion refers to the tangible effects of the transformation.

- Acceptability: the ability to ensure that the integration of PV systems with the heritage building is accepted not only by the clients and designers but also by the direct, indirect and potential users of the building. The criterion refers to the intangible effects of the transformation.

The Compatibility criterion refers to the following sub-criteria:

- Reversibility: ability to remove added elements or materials or to reinstall those removed.

- Conservation of material: use of materials and products which do not compromise the preservation of the building or its parts; the choice of technological solutions which minimise the loss of materials.

- Conservation of the construction system: protection of the construction techniques and the relationships linking the elements of the building, as evidence of the material culture of a specific era or evolution over time.

- Durability of transformation: preventing the added elements from being affected by a rapid degradation process, which would also cause negative effects on the pre-existing elements.

- Preventing decay/breakdown caused by transformation: preventing new materials, new elements, changes in the layout of elements or spaces from damaging the building or accelerating its degradation process.

The Acceptability criterion refers to the following sub-criteria:

- Recognisability of the original construction system: ensuring the identification of the building's construction conception, by using materials and techniques which will not hide its signs.

- Respecting collective memory: ensuring that the transformations do not alter the recognition of the heritage building as an element of social identity, with symbolic values.

- Preservation of aesthetic relationships with the landscape: preserving the morphological, dimensional and proportional relationships between the building and its environment.

- Preservation of building's appearance: preserving the building's image by not altering the shape, size and proportions of the building as a whole, as well as its constituent elements, and preserving the quality of the finishes (colour, texture, grain).

- Recognisability of the transformation: ensuring a clear differentiation between new and pre-existing elements, avoiding mimicry.

The definition of evaluation criteria is the first step towards the development of a decision-support methodology. Actually, no design solution can be acceptable or not acceptable in absolute, but each case has to be considered on a case by case basis. The evaluation should consider the higher or lower importance of each criterion based on the characteristics of the building and its context. The criteria and sub-criteria defined can be weighted differently according to the specific characteristics of the building to be upgraded with solar technologies. The values assigned to the building and the context in the local area by the community concerned should also be considered. A further critical point in the decision-making process is the state of repair of the building to be rehabilitated. The different starting conditions direct the project towards differentiated solutions, to obtain a result that meets the criteria of both compatibility and acceptability. The research proposes the introduction of a pre-assessment grid for the project (Figure 4) based on three alternatives regarding the building's state of repair: (1) ruin; (2) part reconstruction/replacement; (3) well-preserved. These three conditions will lead to defining the weights to be assigned to the sub-criteria according to a logic that promotes clearly recognizable projects (designed with contemporary architectural language) for buildings in a state of ruin. Pre-assessment 
also allows more leeway in the redesign of parts of the envelope that have previously been replaced with elements not compatible with the pre-existing construction system. Greater attention to preserving the appearance and construction logic of heritage buildings is required for well-preserved ones.

\subsection{A synergy among the Excellences to Get out of the Impasse}

Technological innovation-in particular the set of solutions-oriented to energy efficiency and widespread energy production-can be a way to combine instances of architectural conservation with the new needs of the contemporary lifestyle $[102,103]$. Compliance with standards and regulations also requires higher performance.

An increasing number of products are aimed at reducing the aesthetic, hence cultural, the impact of projects aimed at increasing the energy sustainability of historic buildings [104-107]. Companies that produce building materials operate in an ever-growing market that offers progressively less invasive solutions. There are photovoltaic tiles (with photovoltaic cells placed in the central part of each tile), photovoltaic modules alternated with the brick elements of the roof. Are also remarkable the "invisible" photovoltaic systems produced in collaboration with ENEA. Monocrystalline silicon photovoltaic cells are hidden by a coating transparent to solar radiation in polymeric roof tiles. Pavements of urban spaces made of walkable photovoltaic panels-similar to those used for flat roofs-are designed. Plasters or photovoltaic cladding materials that mimic stone or wood are being tried out.

The use of these products cannot be the only way to address such a complex and multifaceted problem. First, because these systems, aiming to mimic traditional building materials, pose problems of authenticity and recognizability, issues long debated in the scientific community. However, mainly, because even RES technologies are signs of values to be preserved to protect our future, which is the future of the Earth. Such values can be summarised under the word sustainability.

Furthermore, the widespread cultural heritage is a vulnerable element, but most of all it is the identity and wealth of the Italian territories, thus the overall quality of the Historic Urban Landscape $[17,32,105]$. This quality is a resource for development and makes Italy an attractive place for living. Therefore, the research of solutions for the coexistence of heritage buildings and energy production systems from renewables is crucial in Italy and requires specific evaluation methodologies.

The strategy for integrating solar technologies in heritage buildings neither should consist of compromising the cultural values of the architectural heritage nor should lead to hiding new elements, which are gradually becoming part of our landscape. The solution to this dilemma should be found by leveraging the power of culture to generate new culture and new values.

Indeed, the more effective solutions among the projects implemented on buildings of significant cultural value are those which do not hide the PV systems, but creatively turn those systems into elements embedded in the cultural enjoyment and production (Figures 2, 5 and 6) [108]. Therefore, the architectural heritage requires synergies between scientific and technological research, artistic production and industrial design. Art and design can become drivers for a more effective and fast development of an already growing production sector, the RES industry and, more generally, the Green Economy. The strategy to be pursued requires the use of the greatest human resource, creativity. According to Luigi Fusco Girard, "Creativity as immaterial capital becomes the real "strength" of a territory/city, more important than financial/infrastructural capital. [ . . ] Creativity also concerns a new way of living in the city for its inhabitants: their creative capacity of combining/integrating old values into a modern vision (the ancient and the new; traditional and modernity)» ([109]; p. 56). The creative effort to overcome the impasse requires synergism of the research, design and art community. From such synergism, we can realistically look forward to a new development trend based on the combined enhancement of two strategic resources, the culture and nature. 


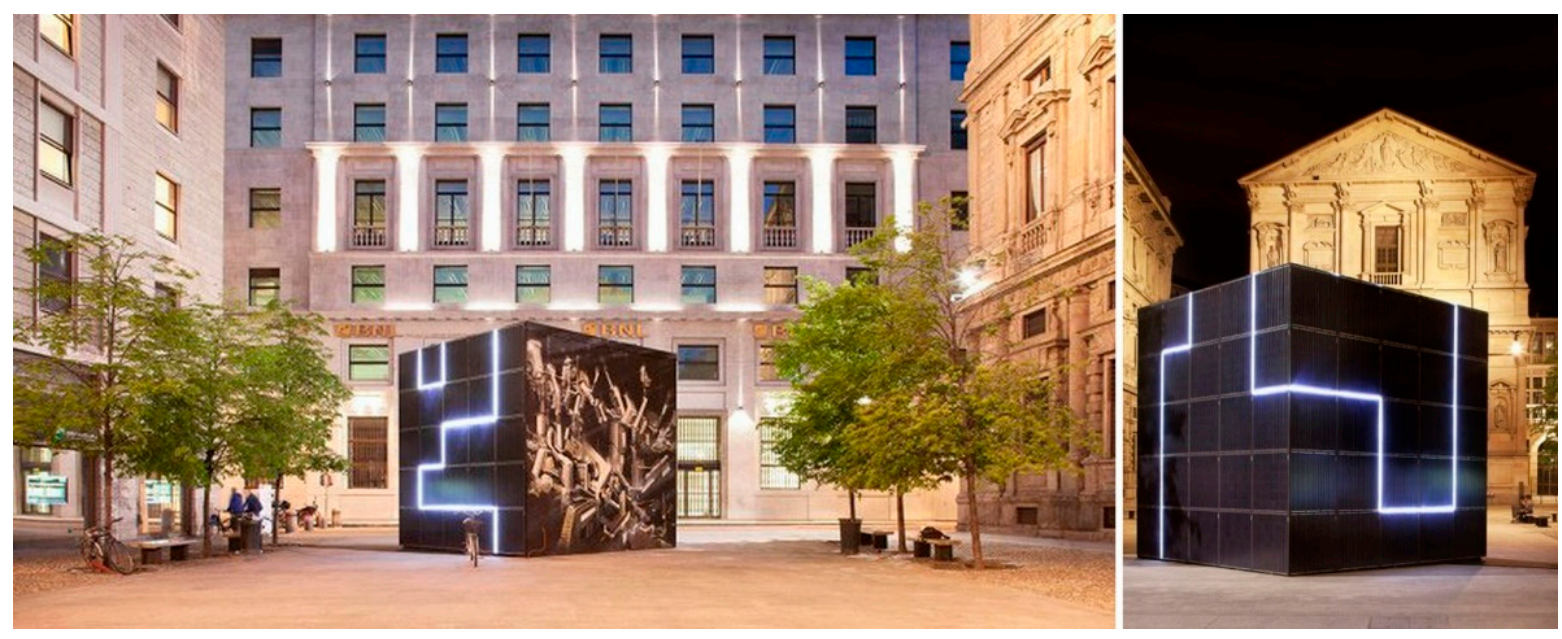

Figure 5. Public installation e-QBO, a photovoltaic (PV) cube designed by the architect Romolo Stanco. E-QBO functions as a photovoltaic accumulator and communication hub [110].
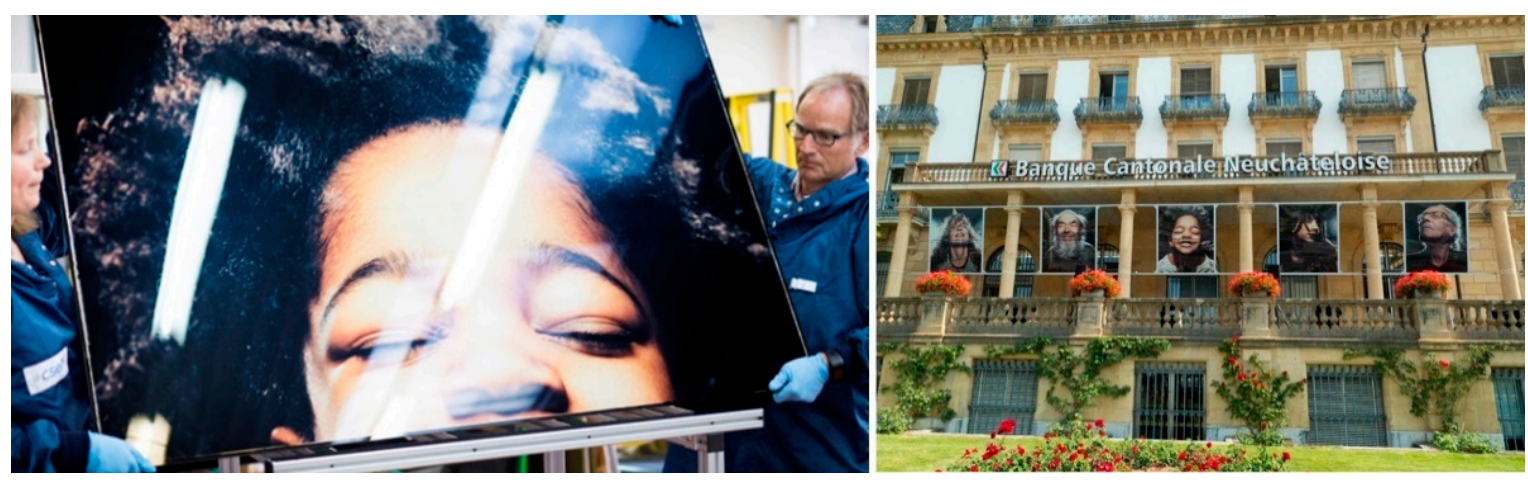

Figure 6. KALEO exhibition taking place in the BCN gardens in Neuchâtel. The exhibition features panels with portraits by Swiss photographer Guillaume Perret, showing facial expressions of people who radiate energy, and one by student Etienne Wildi, winner of the KALEO competition [111,112].

\section{Conclusions}

The need for creativity in the field of Green building solutions is as strong in Italy as it is in Europe. And it is also one of the core drivers within the European Community's recovery strategy to overcome the Covid-19 crisis.

According to the idea of a Renovation Wave for Europe, Ursula von der Leyen in her State of the Union speech on 16 September 2020 announced the launch of the New European Bauhaus, an incubator for innovation and creativity to drive activities in the field of the sustainable design. President von der Leyen declared that NextGenerationEU «needs to be a new cultural project for Europe. Every movement has its own look and feel. We need to give our systemic change its own distinct aesthetic, to match style with sustainability» [113]. The idea is to create a multidisciplinary network, by mobilising creative minds to imagine solutions for a sustainable future.

Through a review of study cases and of guidelines provided by European and Italian governments, the paper leads to identify evaluation criteria for the introduction of PV systems in pre-industrial buildings. Such criteria, which are based on architectural heritage values, allow for assessing the consistency of the building envelope alteration with conservation issues in projects involving PV systems. The paper also leads to a classification hypothesis for heritage buildings, based on their conservation status. For each class, appropriate intervention strategies are identified and differential weights to the criteria are given, to evaluate design alternatives. 
The criteria and sub-criteria for the integrability of PV systems and architectural heritage proposed in this paper can contribute to progress in the Renovation Wave for Europe. However, their effectiveness should be assessed only through multidisciplinary research processes and experimentation involving art and design creation. In particular, the current research on evaluation criteria is paving the way for two possible application areas. The first involves the development of decision support methods to evaluate the impacts (in terms of protection of building identity and landscape) of rehabilitation projects including green technologies in the built environment. The second scope of the application relates to the potential participation in the creative process launched by Europe, as a guideline for developing design solutions and product lines able to increase the heritage value of buildings through the creation of new heritage pieces, consisting of works of art and industrial design.

Funding: This research received no external funding.

Institutional Review Board Statement: Not applicable.

Informed Consent Statement: Not applicable.

Data Availability Statement: Not applicable.

Acknowledgments: I would like to thank Francesco Nocera, co-editor of the special issue "The Application of Renewable Energy in Sustainable Architecture", for involving me in his research activities on the topic of the integration of solar technologies in the architectural heritage. As well, I would like to thank the anonymous reviewers, who have significantly contributed to the quality of this article. I would also express my deep gratitude to Maria Rosaria De Medici, for providing me with precious ideas on how to set up the narrative structure of this paper.

Conflicts of Interest: The author declares no conflict of interest.

\section{References}

1. Kellner, D. Theorizing Globalization. Soc. Theory 2002, 20, 285-305. [CrossRef]

2. United Nations Transforming Our World: The 2030 Agenda for Sustainable Development; Unied Nations: New York, NY, USA, 2015.

3. United Nations Draft Outcome Document of the United Nations Conference on Housing and Sustainable Urban Development (Habitat III); United Nations: New York, NY, USA, 2016.

4. European Commission Urban Agenda for the EU-Pact of Amsterdam; European Commission: Amsterdam, The Netherlands, 2016.

5. European Commission The European Green Deal. Communication from the Commission to the European Parliament, the European Council, the Council, the European Economic and Social Committee and the Committee of the Regions; European Commission: Brussels, Belgium, 2019.

6. European Commission Sustainable Europe Investment Plan (SEIP)-European Green Deal Investment Plan (EGDIP); European Commission: Brussels, Belgium, 2020.

7. Fusco Girard, L.; Nocca, F. Il Modello Di Città Circolare Come Modello Di Sviluppo per Le Città. BDC Boll. Del Cent. Calza Bini 2019, 19, 307-335.

8. European Commission A Renovation Wave for Europe-Greening Our Buildings, Creating Jobs, Improving Lives. Available online: https:/ / ec.europa.eu/energy/sites/ener/files/eu_renovation_wave_strategy.pdf (accessed on 15 December 2020).

9. Trovato, M.R.; Nocera, F.; Giuffrida, S. Life-Cycle Assessment and Monetary Measurements for the Carbon Footprint Reduction of Public Buildings. Sustainability 2020, 12, 3460. [CrossRef]

10. Calligaro, O. From 'European Cultural Heritage' to 'Cultural Diversity'?: The Changing Core Values of European Cultural Policy. Polit. Eur. 2014, 45, 60-85. [CrossRef]

11. European Parliament Debates of the European Parliament: Sitting of 13 May 1974 "European Cultural Heritage". Off. J. Eur. Communities 1974, C62, 1-10.

12. ISTAT BES 2019_Il Benessere Equo e Sostenibile in Italia; Istituto Nazionale Di Statistica: Roma, Italy, 2019.

13. ISTAT-Istituto Nazionale Di Statistica. Available online: http:/ / www.istat.it (accessed on 1 January 2021).

14. Nocera, F.; Lo Faro, A.; Costanzo, V.; Raciti, C. Daylight Performance of Classrooms in a Mediterranean School Heritage Building. Sustainability 2018, 10, 3705. [CrossRef]

15. Crova, C. Le Linee Guida Di Indirizzo per Il Miglioramento Dell'efficienza Energetica Nel Patrimonio Culturale. Architettura, Centri e Nuclei Storici Ed Urbani: Un Aggiornamento Della Scienza Del Restauro. In Proceedings of the Le Nuove Frontiere del Restauro. Trasferimenti, Contaminazioni, Ibridazioni, Atti del XXXIII Convegno Internazionale Scienza e Beni Culturali, Brixen, Italy, 27-30 June 2017; Biscontin, G., Driussi, G., Eds.; Arcadia Ricerche: Venezia, Italy, 2017; pp. 179-188.

16. Carbonara, G. Energy Efficiency as a Protection Tool. Energy Build. 2015, 95. [CrossRef] 
17. Pinto, M.R. Il Riuso Edilizio. Procedure, Metodi Ed Esperienze; UTET Libreria: Turin, Italy, 2004.

18. Caterina, G. Strategie Innovative per Il Recupero Delle Città Storiche. Techne 2016, 12, 33-35. [CrossRef]

19. Greffe, X. Is Heritage an Asset or a Liability? J. Cult. Herit. 2004, 301-309. [CrossRef]

20. Cunnington, P. Change of Use: The Conversion of Old Buildings; Alpha Books: London, UK, 1988.

21. Plevoets, B.; Van Cleempoel, K. Adaptive Reuse of the Built Heritage. Concepts and Cases of an Emerging Discipline; Routledge: Abingdon, UK, 2019.

22. Ashworth, G.J.; Graham, B. Senses of Place: Senses of Time; Routledge: London, UK, 2017.

23. Settis, S. Italia S.p.A. L'assalto Al Patrimonio Culturale; Einaudi: Turin, Italy, 2002.

24. Fusco Girard, L. Sustainability, Creativity, Resilience: Toward New Development Strategies of Port Areas through Evaluation Processes. Int. J. Sustain. Dev. 2010, 13, 161-184. [CrossRef]

25. Benjamin, W. The Work of Art in the Age of Mechanical Reproduction. In Illuminations; Arend, H., Ed.; Schocken Books: New York, NY, USA, 1969.

26. Council of Europe Convention on the Value of Cultural Heritage for Society. Available online: https://www.coe.int/en/web/ conventions / full-list/- / conventions / treaty/199 (accessed on 28 December 2020).

27. UNESCO Intergovernmental Committee for the Protection of the World Cultural and Natural Heritage. Operational Guidelines for the Implementation of the World Heritage Convention; UNESCO: Paris, France, 2008.

28. Fusco Girard, L.; Vecco, M. Genius Loci: The Evaluation of Places between Instrumental and Intrinsic Values. BDC Boll. Del Cent. Calza Bini 2019, 2, 473-495.

29. Powell, K. Architecture Reborn. Converting Old Buildings for New Uses; Rizzoli International Publications, Inc.: New York, NY, USA, 1999.

30. Della Torre, S. Italian Perspective on the Planned Preventive Conservation of Architectural Heritage. Front. Archit. Res. 2020. [CrossRef]

31. ICOMOS EU—Cherishing Heritage-Quality Principles for Intervention on Cultural Heritage. Available online: https:/ / europa. eu/cultural-heritage/cherishing-heritage-quality-principles-intervention-cultural-heritage_en (accessed on 15 December 2020).

32. ICOMOS The Nara Document on Authenticity. Available online: https://www.icomos.org/charters/nara-e.pdf (accessed on 15 December 2020).

33. Viola, S.; De Medici, S.; Riganti, P. The circular economy and built environment. Maintenance, rehabilitation and adaptive reuse: Challenging strategies for closing loops. In An Introduction to the Circular Economy; Morganti, P., Ed.; Nova Science Publishers: Hauppauge, NY, USA, 2021.

34. UNESCO. Recommendation on the Historic Urban Landscape; UNESCO World Heritage Centre: Paris, France, 2011.

35. Stahel, W.R. The Circular Economy. Nature 2016, 531, 435-438. [CrossRef] [PubMed]

36. Stone, S. Foreword. In Adaptive Reuse of the Built Heritage. Concepts and Cases of an Emerging Discipline; Plevoets, B., Van Cleempoel, K., Eds.; Routledge: Abingdon, UK, 2019; pp. xvii-xix.

37. Ball, R.M. Re-Use Potential and Vacant Industrial Premises: Revisiting the Regeneration Issue in Stoke-on-Trent. J. Prop. Res. 2002, 19, 93-110. [CrossRef]

38. Bon, R.; Hutchinson, K. Sustainable Construction: Some Economic Challenges. Build. Res. Inf. 2000, 28, 310-314. [CrossRef]

39. Caccavelli, D.; Gugerli, H. TOBUS-A European Diagnosis and Decision-Making Tool for Office Building Upgrading. Energy Build. 2002, 34, 113-119. [CrossRef]

40. The Construction Sector System Approach: An International Framework. Report by CIB W55-W65 Construction Industry Comparative Analysis Project Group; Carassus, J. (Ed.) CIB: Rotterdam, The Netherlands, 2004.

41. Gallant, B.T.; Blickle, F.W. The Building Decommissioning Assessment: A New Six-Step Process to Manage Redevelopment of Brownfields with Major Structures. Environ. Pract. 2005, 7, 97-107. [CrossRef]

42. Kohler, N. A European Perspective on the Pearce Report; Policy and Research. Build. Res. Inf. 2006, 34, 287-294. [CrossRef]

43. Bradley, P.E.; Kohler, N. Methodology for the Survival Analysis of Urban Building Stocks. Build. Res. Inf. 2007, 35, 529-542. [CrossRef]

44. Van Bueren, E.; De Jong, J. Establishing Sustainability: Policy Successes and Failures. Build. Res. Inf. 2007, 35, 543-556. [CrossRef]

45. Bullen, P.A.; Love, P.E.D. The Rhetoric of Adaptive Reuse or Reality of Demolition: Views from the Field. Cities 2010, 27, 215-224. [CrossRef]

46. European Commission European Construction Sector Observatory. Trend Paper-EU Construction Sector: In Transition towards a Circular Economy. Available online: https:/ / ec.europa.eu/docsroom/documents/34904 (accessed on 10 November 2020).

47. CIC. Construction Intelligence Centre Global Construction Outlook to 2023-Q1 2019 Update. Available online: https:/ /www. globaldata.com/store/report/gdcn0012go--global-construction-outlook-to-2022-q4-2018-update (accessed on 10 November 2020).

48. Wilkinson, S.J.; James, K.; Reed, R. Using Building Adaptation to Deliver Sustainability in Australia. Struct. Surv. 2009, $27,46-61$. [CrossRef]

49. CRESME RI.U.SO 03. Ristrutturazione Edilizia, Riqualificazione Energetica, Rigenerazione Urbana. Available online: http: //www.old.awn.it/AWN/Engine/RAServeFile.php/f/RAPPORTO_riuso03.pdf (accessed on 20 December 2020).

50. HammershØj, L.G. Creativity as a Question of Bildung. J. Philos. Educ. 2009, 43, 545-558. [CrossRef]

51. Kembel, G. Preface. In Make Space: How to set the stage for creative collaboration; John Wiley \& Sons: New York, NY, USA, 2012. 
52. Martin, P. What Are Creative Spaces? Making Space for Creativity; University of Brighton: Brighton, UK, 2010.

53. Institut de Cultura Barcelona Culture: Fourth Pillar of Sustainable Development. Available online: http://www.agenda21culture. net/sites/default/files/files/documents/en/zz_culture4pillarsd_eng.pdf (accessed on 20 December 2020).

54. Pereira Roders, A.; Van Oers, R. Editorial: Bridging Cultural Heritage and Sustainable Development. J. Cult. Herit. Manag. Sustain. Dev. 2011, 1, 5-14. [CrossRef]

55. Lucchi, E.; Polo López, C.S.; Franco, G. A Conceptual Framework on the Integration of Solar Energy Systems in Heritage Sites and Buildings. In Proceedings of the International Conference Florence Heri-tech: The Future of Heritage Science and Technologies, Florence, Italy, 13-15 May 2020.

56. International Energy Agency (IEA). SHC Task 59/EBC Annex 76. Historic Buildings. Deep Renovation of Historic Buildings towards Lowest Possible Energy Demand and $\mathrm{CO}_{2}$ Emission (NZEB). Available online: https://task59.iea-shc.org/Data/Sites/ 59/media/documents/iea-shc-task59-annex.pdf (accessed on 1 January 2021).

57. Fonseca, J.A.; Schlueter, A. Novel Approach for Decentralized Energy Supply and Energy Storage of Tall Buildings in Latin America Based on Renewable Energy Sources: Case Study—Informal Vertical Community Torre David, Caracas—Venezuela. Energy 2013, 53, 93-105. [CrossRef]

58. Zhang, S. Analysis of DSPV (Distributed Solar PV) Power Policy in China. Energy 2016, 98, 92-100. [CrossRef]

59. Milan, C.; Bojesen, C.; Nielsen, M.P. A Cost Optimization Model for 100\% Renewable Residential Energy Supply Systems. Energy 2012, 48, 118-127. [CrossRef]

60. Munari Probst, M.C.; Roecker, C. Criteria for Architectural Integration of Active Solar Systems IEA Task 41, Subtask A. Energy Procedia 2012, 30, 1195-1204. [CrossRef]

61. Farkas, K. (Ed.) Designing Photovoltaic Systems for Architectural Integration. Criteria and Guidelines for Product and System Developers. Report T.41.A.3/2: IEA SHC Task 41. Available online: https://task41.iea-shc.org/Data/Sites/1/publications/task4 1A3-2-Designing-Photovoltaic-Systems-for-Architectural-Integration.pdf (accessed on 10 November 2020).

62. Polo López, C.S.; Frontini, F. Energy Efficiency and Renewable Solar Energy Integration in Heritage Historic Buildings. Energy Procedia 2014, 48, 1493-1502. [CrossRef]

63. Lucchi, E.; Garegnani, G.; Maturi, L.; Moser, D. Architectural Integration of Photovoltaic Systems in Historic Districts. The Case Study Pf Santiago de Compostela. In Proceedings of the International Conference in Energy Efficiency in Historic Buildings, Madrid, Spain, 29-30 September 2014.

64. Rotilio, M.; De Berardinis, P.; Cucchiella, F. Renewable Energy Sources in Minor Historical Centers. New Scenarios of Sustainable Development of the Territory. Green Energy Technol. 2015, 173, 75-106. [CrossRef]

65. Battisti, A. Strategie per Il Retrofitting Degli Edifici Storici. La Riprogettazione Dei Sistemi Impiantistico Tecnologici, Volti Al Conseguimento Del Benessere Fisico e Ambientale, Al Contenimento Dei Consumi Energetici e All'integrazione Delle Energie Rinnovabili. Antincendio 2011, 2, 106-110.

66. Chow, T.T. A Review on Photovoltaic/Thermal Hybrid Solar Technology. Renew. Energy 2020, 87, 365-379. [CrossRef]

67. Bellia, L.; D'Ambrosio Alfano, F.R.; Giordano, J.; Ianniello, E.; Riccio, G. Energy Requalification of a Historical Building: A Case Study. Energy Build. 2015, 95, 184-189. [CrossRef]

68. Moschella, A.; Salemi, A.; Lo Faro, A.; Sanfilippo, G.; Detommaso, M.; Privitera, A. Historic Buildings in Mediterranean Area and Solar Thermal Technologies: Architectural Integration vs Preservation Criteria. Energy Procedia 2013, 42, 416-425. [CrossRef]

69. Nocera, F.; Caponetto, R.; Giuffrida, G.; Detommaso, M. Energetic Retrofit Strategies for Traditional Sicilian Wine Cellars: A Case Study. Energies 2020, 13, 3237. [CrossRef]

70. Lucchi, E.; Tabak, M.; Carì, V.; Perna, M. BiPV Ed Edifici Storici: L'integrazione è Possibile? In Proceedings of the $34^{\circ}$ Convegno Nazionale Bologna-Soluzioni Impiantistiche per Edifici a Basso Consumo di Energia: Indirizzi Normativi, Tecnologie e Strategie di Gestione, Bologna, Italy, 20 October 2016; pp. 1-14.

71. Repubblica e Cantone Ticino Dipartimento del Territorio Sezione Dello Sviluppo Territoriale Linee Guida Cantonali. In-terventi Nei Nuclei Storici. Criteri Di Valutazione Paesaggistica Nell'ambito Della Procedura Edilizia. Available online: https: / / www4.ti. ch/fileadmin/DT/direttive/DT_DSTM_SST/Interventi_nei_nuclei_storici_022016.pdf (accessed on 20 December 2020).

72. Throsby, D. The Value of Cultural Heritage: What Can Economics Tell Us? In Capturing the Public Value of Heritage. The Proceedings of the London Conference; Clark, K., Ed.; English Heritage: Swindon, UK, 2006; pp. 40-43.

73. Broström, T.; Svahnström, K. Solar Energy and Cultural-Heritage Values. In Proceedings of the World Renewable Energy Congress, Linköping, Sweden, 8-13 May 2011; Volume 57.

74. Giuffrida, S.; Gagliano, F.; Nocera, F.; Trovato, M.R. Landscape Assessment and Economic Accounting in Wind Farm Programming: Two Cases in Sicily. Land 2018, 7, 120. [CrossRef]

75. PVACCEPT Project. Available online: http://www.pvaccept.de/pvaccept/eng/index.htm (accessed on 16 December 2020).

76. Galatioto, A.; Ciulla, G.; Ricciu, R. An Overview of Energy Retrofit Actions Feasibility on Italian Historical Buildings. Energy 2017, 137, 991-1000. [CrossRef]

77. Cristofari, C.; Carutasiu, M.B.; Canaletti, J.L.; Norvaišienè, R.; Motte, F.; Notton, G. Building Integration of Solar Thermal Systems-Example of a Refurbishment of a Church Rectory. Renew. Energy 2019, 137, 67-81. [CrossRef]

78. Webb, A.L. Energy Retrofits in Historic and Traditional Buildings: A Review of Problems and Methods. Renew. Sustain. Energy Rev. 2017, 77, 748-759. [CrossRef] 
79. Thebault, M.; Clivillé, V.; Berrah, L.; Desthieux, G. Multicriteria Roof Sorting for the Integration of Photovoltaic Systems in Urban Environments. Sustain. Cities Soc. 2020, 60. [CrossRef]

80. Florio, P.; Probst, M.C.M.; Schüler, A.; Scartezzini, J.L. Visual Prominence vs Architectural Sensitivity of Solar Applications in Existing Urban Areas: An Experience with Web-Shared Photos. Energy Procedia 2017, 122, 955-960. [CrossRef]

81. Munari, M.C.; Roecker, C. Solar Energy Promotion \& Urban Context Protection: LESO-QSV (Quality-Site-Visibility)Method. In Proceedings of the 31th International PLEA Conference-ARCHITECTURE IN (R)EVOLUTION, Bologna, Italy, 9-11 September 2015.

82. Florio, P.; Munari Probst, M.C.; Schüler, A.; Roecker, C.; Scartezzini, J.L. Assessing Visibility in Multi-Scale Urban Planning: A Contribution to a Method Enhancing Social Acceptability of Solar Energy in Cities. Sol. Energy 2018, 173, 97-109. [CrossRef]

83. Munari Probst, M.C.; Roecker, C. Criteria and Policies to Master the Visual Impact of Solar Systems in Urban Environments: The LESO-QSV Method. Sol. Energy 2019, 184, 672-687. [CrossRef]

84. Scognamiglio, A. 'Photovoltaic Landscapes': Design and Assessment. A Critical Review for a New Transdisciplinary Design Vision. Renew. Sustain. Energy Rev. 2016, 55, 629-661. [CrossRef]

85. Lidelöw, S.; Örn, T.; Luciani, A.; Rizzo, A. Energy-Efficiency Measures for Heritage Buildings: A Literature Review. Sustain. Cities Soc. 2019, 45, 231-242. [CrossRef]

86. Cabeza, L.F.; de Gracia, A.; Pisello, A.L. Integration of Renewable Technologies in Historical and Heritage Buildings: A Review. Energy Build. 2018, 177, 96-111. [CrossRef]

87. Franek, J.; Kresta, A. Judgment Scales and Consistency Measure in AHP. Procedia Econ. Financ. 2014, 12, 164-173. [CrossRef]

88. Saaty, T.L. Decision Making — the Analytic Hierarchy and Network Processes (AHP/ANP). J. Syst. Sci. Syst. Eng. 2004, 13, 1-35. [CrossRef]

89. Rizzo, I.; Throsby, D. Chapter 28 Cultural Heritage: Economic Analysis and Public Policy. Handb. Econ. Art Cult. 2006, 1, 983-1016.

90. Greffe, X. Creativity: The strategic role of cultural landscapes. In Sustainable City and Creativity: Promoting Creative Urban Initiatives; Fusco Girard, L., Baycan, T., Nijkamp, P., Eds.; Routledge: London, UK, 2016; pp. 199-224. ISBN 9781315611464.

91. Nocca, F.; Fusco Girard, L. Towards an Integrated Evaluation Approach for Cultural Urban Landscape Conservation/Regeneration. Region 2018. [CrossRef]

92. Throsby, D. On the Sustainability of Cultural Capital. Unpubl. Pap. 2006. [CrossRef]

93. Nijkamp, P. Economic Valuation of Cultural Heritage. In The Economics of Uniqueness. Investing in Historic City Cores and Cultural Heritage Assets for Sustainable Development; Licciardi, G., Amirtahmasebi, R., Eds.; The World Bank: Washington, DC, USA, 2012 pp. 75-106.

94. Caterina, G.; Pinto, M.R.; Fabbricatti, K.; Oppido, S.; De Medici, S.; De Toro, P.; Bianchi, A. Reusing and Managing the “Real Albergo de' Poveri" of Naples: Evaluation and Re-Design for Improved Efficiency. In Proceedings of the CIB W70 International Symposium on the "Facilities, Management and Maintenance", Hong Kong, China, 7-8 December 2014; Shiem-Shin, D.T., Johnes, K., Hinks, J., Eds.; The Hong Kong Polytechnic University: Hong Kong, China, 2004; pp. 129-139.

95. De Medici, S.; Senia, C. Enhancement of Abandoned Buildings. Rudinì Winery in Pachino; FrancoAngeli: Milan, Italy, 2014.

96. Pinto, M.R.; De Medici, S.; Senia, C.; Fabbricatti, K.; De Toro, P. Building Reuse: Multi-Criteria Assessment for Compatible Design. Int. J. Des. Sci. Technol. 2017, 22.

97. Viola, S.; Diano, D. Repurposing the Built Environment: Emerging Challenges and Key Entry Points for Future Research. Sustainability 2019, 11, 4669. [CrossRef]

98. Viollet-le-Duc, E.E. Dictionnaire Raisonné de La Architecture Française Du XI Au XVI Siècle, English, ed.; Édition Bance-Morel: Paris, France, 1854.

99. Ruskin, J. The Seven Lamps of Architecture. Bull. Am. Art-Union 1849, 2. [CrossRef]

100. Franco, G. Solar Powered Energy and Eco-Efficiency in a UNESCO Site. Criteria and Recommendations for the National Park of Cinque Terre, Italy. Energy Build. 2018, 174. [CrossRef]

101. Polo Lopez, C.; Lucchi, E.; Franco, G. Acceptance of Building Integrated Photovoltaic (BIPV) in Heritage Buildings and Landscapes: Potentials, Barrier and Assessment Criteria. In Proceedings of the Rehabend Conference, Construction Pathology, Rehabilitation Technology and Heritage Management, Granada, Spain, 24-27 March 2020; pp. 1636-1644.

102. De Berardinis, P.; Fecondo, P. Architectural Integration of Solar Systems. Evaluation Criteria and Intervention Strategies for Minor Historical Centres. In Proceedings of the International Conference on Energy Management in Cultural Heritage, Dubrovnik, Croatia, 6-8 April 2011; Croatia United Nations Development Programme: Dubrovnik, Croatia, 2011; pp. 1-13.

103. Milone, D.; Peria, G.; Pitruzzella, S.; Rizzo, G. Are the Best Available Technologies the Only Viable for Energyinterventions in Historical Buildings? Energy Build. 2015, 95, 39-46. [CrossRef]

104. Jelle, B.P.; Breivik, C.; Drolsum Røkenes, H. Building Integrated Photovoltaic Products: A State-of-the-Art Review and Future Research Opportunities. Sol. Energy Mater. Sol. Cells 2012, 100, 69-96. [CrossRef]

105. Jelle, B.P. Building Integrated Photovoltaics: A Concise Description of the Current State of the Art and Possible Research Pathways. Energies 2016, 9, 21. [CrossRef]

106. Zhang, K.; Qin, C.; Yang, X.; Islam, A.; Zhang, S.; Chen, H.; Han, L. High-Performance, Transparent, Dye-Sensitized Solar Cells for See-through Photovoltaic Windows. Adv. Energy Mater. 2014, 4. [CrossRef] 
107. Nguyen, T.T.; Patel, M.; Kim, S.; Mir, R.A.; Yi, J.; Dao, V.A.; Kim, J. Transparent Photovoltaic Cells and Self-Powered Photodetectors by $\mathrm{TiO} 2 / \mathrm{NiO}$ Heterojunction. J. Power Sources 2021, 481. [CrossRef]

108. Hermannsdörfer, I.; Rüb, C. Solar Design. Photovoltaics for Old Buildings, Urban Space, Landscapes; Jovis: Berlin, Germany, 2006.

109. Fusco Girard, L. Creativity and the human sustainable city: Principles and approaches for nurturing city resilience. In Sustainable City and Creativity: Promoting Creative Urban Initiatives; Routledge: London, UK, 2012.

110. E-QBO, Immagini Del Cubo Fotovoltaico. Available online: https://www.greenstyle.it/gallerie/e-qbo-immagini-del-cubofotovoltaico (accessed on 20 December 2020).

111. Smile-Your Photos Can Generate Energy! Available online: https://www.csem.ch/Page.aspx?pid=46630 (accessed on 16 December 2020).

112. Innovative Aesthetics: Illustrated Solar Panels. Available online: http://www.behindenergy.com/innovative-aestheticsillustrated-solar-panels/?lang=en (accessed on 16 December 2020).

113. Von der Leyen, U. Building the World We Want to Live in: A Union of Vitality in a World of Fragility, State of the Union Address by President von Der Leyen at the European Parliament Plenary-Speech. 16 September 2020. 